\title{
Middle to late Pleistocene climatic and depositional environmental changes recorded in the drilled core of lacustrine sediments in the Kathmandu Valley, central Nepal
}

\author{
Harutaka Sakai and Members of Paleo-Kathmandu Lake Drilling Project \\ Department of Earth Sciences, Kyushu University, Ropponmatsu, Fukuoka, 810-8560, JAPAN \\ For correspondence, E-mail: hsake@rc.kyushu-u.ac.jp
}

\begin{abstract}
Since October 2000, we have undertaken core-drilling for pure academic purposes at Kathmandu, Nepal, in order to clarify the continuous paleoclimatic records in the southern slope of the Himalaya and to reconstruct the depositional environmental changes of the ancient lake in Kathmandu (Paleo-Kathmandu Lake) during the last one million years. In this project, we also aimed to clarify the uplift history of the Himalaya and its linkage to paleoclimatic and paleo-environmental changes. We could have penetrated black muddy lacustrine sediments, called the
\end{abstract}

Kalimati Formation, at western central part of the valley (RB core at Rabibhawan) in 2000 (Sakai et al 2001) and southern part of the valley (CP core at Champi and JK core at Jorkhu) in 2003 (Figures 1 and 2). We also could have penetrated the lower part of the fanglomerate, called Itaiti Formation and underlying Lukundol Formation which shows marginal lacustrine facies comprising of fluvial and swamp deposits in 2001 (Sakai 2001a).

The longest core drilled at Rabibhawan is $218 \mathrm{~m}$ in length and ranges in age from about $700 \mathrm{ka}$ to $10 \mathrm{ka}$ on the base of

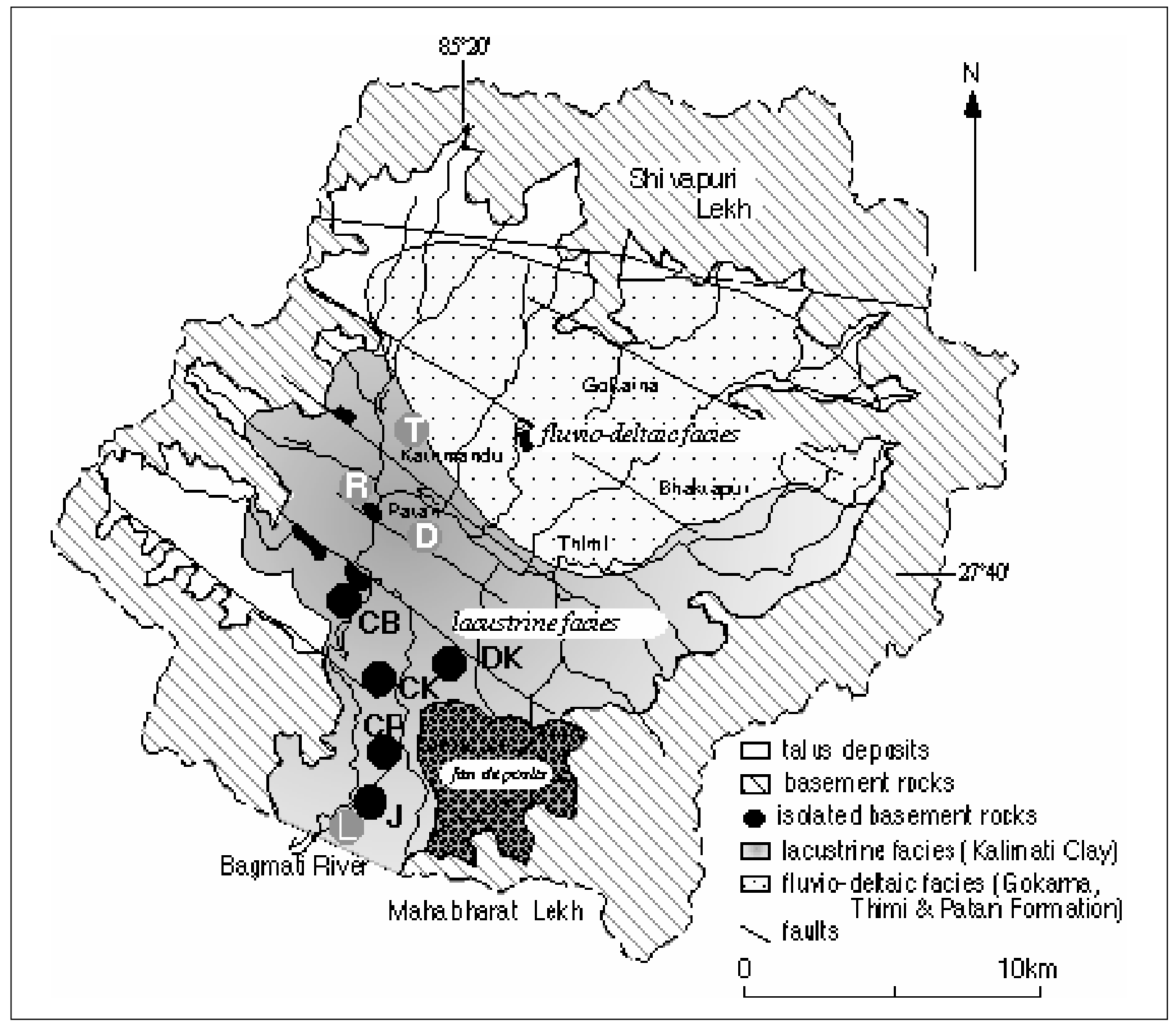

FIGURE 1. Geological outline map of the Kathmandu basin and location of drill-well by Paleo-Kathmandu Lake drilling project. Drilling was carried out in 2000 at T (Tri-Chandra Campus), R(Rabibhawan), D(Disaster Prevention Technical Center at Pulchawk). Drill sites in 2003 are CK (Chayasikot), DK (Dhapakel), CP (Champi) and J (J orkhu). L: lukundol, CB (Chobal). 
paleomagnetic study and AMS $14 C$ dating. Judging from the paleo-magnitic and sedimentological studies of the core from the Lukundol and Itaithi Formation, muddy lacustrinesediments seems to have started their deposition at about $1 \mathrm{Ma}$. The sedimentaion rateof themuddy lacustrinesediments in thelower to middlepartsiseastimated to be $0.2 \mathrm{~mm} / \mathrm{y}$, and that of theupper part is about $0.6 \mathrm{~mm} / \mathrm{y}$ due to smaller compaction.

Surfacegeological survey in the southern part of thevalley and sedimentological study of cores from the Lukundol area suggest that thelakewas born by damingup of theProto-Bagmati river caused by debris flows and following deposition of fanglomerate originated from the Mahabharat Range (frontal range of the Nepal Himalaya) which hasstarted its uplift at about $1 \mathrm{Ma}$ (Sakai et al. 2002).

Three drilled cores at western central part of the valley commonlyshow that the lacustrinesediments, at 9 to $12 \mathrm{~m}$ deep, wereeroded by river at about $12 \mathrm{ka}$. Thedraining out of the lakewater is likely to be triggered by earthquake, which caused by activation of earthquakefault likeas Danuwargaun fault cutting the basin-fill sedimentsat thesouthern margin of the valley (Sakai 2001b). In thenorthern and eastern part of the basin, themuddy lacustrinesedimentsarecovered with thicksandylacustrine delta deposits, Gokarna and Thimi Formation, more than $80 \mathrm{~m}$ thick (Figure1).

Only onesand bed of $6 \mathrm{~m}$ thick is interbedded with muddy lacustrine deposits of RB core. It is attributed to an event bed formed by some tectonic or sedimentological event, because there is no depositional gap between the under- and overlying beds.

$\delta^{13} \mathrm{C}$ value of organic lacustrine mud shows at least seven time fluctuation ranging from -30 to $-19 \%$. A fluctuation diagram of pollen assemblage shows similar pattern to that of $\delta^{13} \mathrm{C}$ value, and indicated that pollens of cold and dry climate increased when $\delta^{13} \mathrm{C}$ has high value. It suggests that grasses includingC4 plants expanded their distribution duringtheglacial period. Total organic carbon (TOC) and carbon/ nitrogen ration $(T / N)$ shows inversed correlation with $\delta^{13} \mathrm{C}$, and pollen concentration hasgood correlation with TOC and C/N. It implies that TOC and pollen concentration werecontrolled by land plants vegetated in the valleyslope. When it was warm and wet climate, C3land plants seem to have expanded their distribution.

Pollen concentration, total valves of diatom and $\mathrm{C} / \mathrm{N}$ ratio before ca. 350 ka shows larger amplitude and larger value than those after $300 \mathrm{ka}$. During the middlePleitocenefrom ca. 650 to $350 \mathrm{ka}$, frequency of diatom valves is characterized by monodominance of Cyclotella sp 1 and sp 2. These curious incidents are likely to be related to MIS stage 11problem.

(Refer to papers by Fujii and Maki on the pollen analysis. On the geochemical study, refer to a paper by Mammpuku. A paper presented by Hayashi discusses on the environmental changes based on fossil diatom. The paleo-environmental changes are also discussed by Kuwahara on the basis of study on the clay minerals.)

\section{References}

Sakai H (ed). 2001. Himalayan Uplift and Paleodimatic Changes in Central Nepal. J Nepal Geol.ogical Society (Special Issue) 25: 155 p

Sakai H, R Fujii and Y Kuwahara. 2002. Changes in the depositional system of the Paleo-Kathmandu Lake caused by uplift of the Nepal Lesser Himalayas. J Asian Earth Sciences 20: 267-276

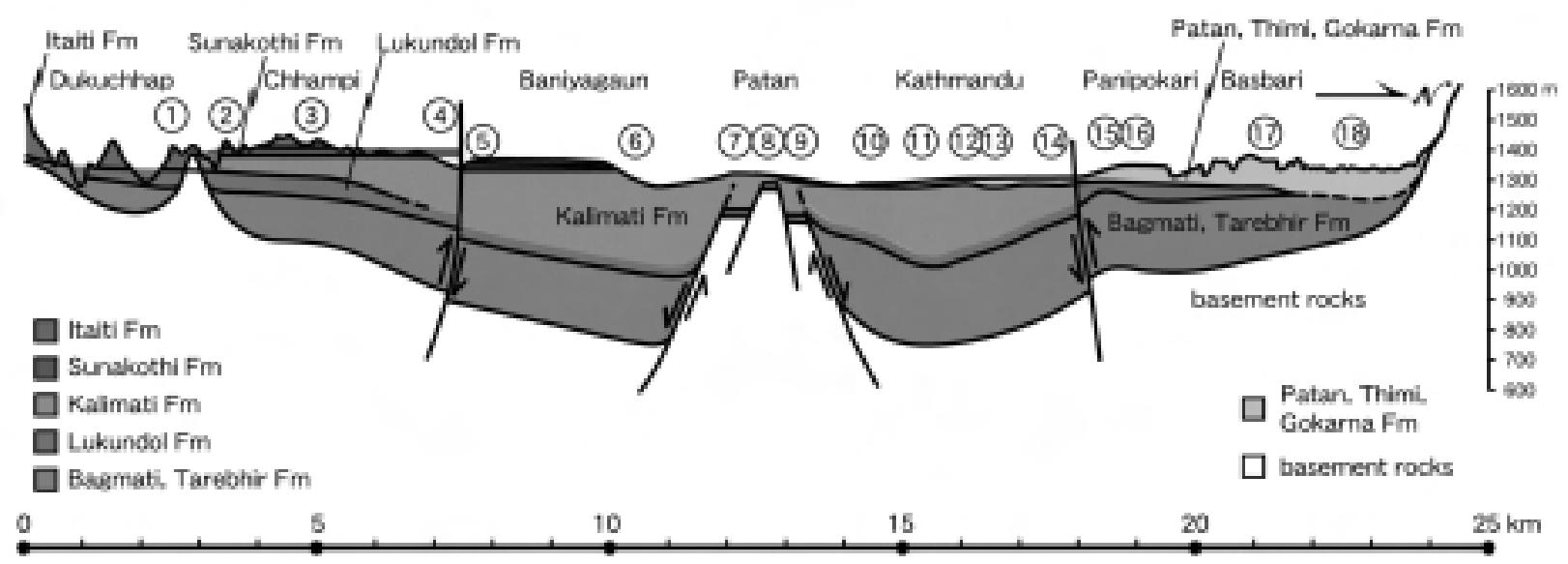

FIGURE 2. Geological cross-section of the Kathmandu Basin based on drill-core data and surface geological survey. No. 1 18: previous drill sites 